\title{
Identification and Characterization of Novel Angiotensin-Converting Enzyme Inhibitors Obtained from Goat Milk
}

\author{
A. Geerlings, ${ }^{11,2}$ I. C. Villar, $\dagger^{2}$ F. Hidalgo Zarco, ${ }^{*} M$. Sánchez, $†$ R. Vera, $†$ A. Zafra Gomez, ${ }^{*}$ \\ J. Boza, ${ }^{\star}$ and J. Duarte† \\ *Department of Biomedicine, Puleva Biotech, Camino de Purchil 66, 18004 Granada, Spain \\ †Department of Pharmacology, School of Pharmacy, University of Granada, Granada, Spain
}

\begin{abstract}
The aim of the present study was to identify and characterize new inhibitory peptides of angiotensin Iconverting enzyme (ACE) from goat milk and to analyze the effect of long-term intake of a goat milk hydrolysatesupplemented (GP-hyd) diet on the development of hypertension in spontaneously hypertensive rats (SHR). Three new inhibitory peptides for ACE (TGPIPN, SLPQ, and SQPK) were isolated. The inhibitory concentration $50 \%\left(\mathrm{IC}_{50}\right)$ values of individual peptides were 316,330 , and $354 \mu \mathrm{mol} / \mathrm{L}$, respectively. Only TGPIPN was found to pass intact a monolayer of Caco-2 cells in small amounts. The SHR fed for 12 wk a diet (GP-hyd) enriched in a hydrolysate containing these peptides (estimated intake of TGPIPN was $230 \mathrm{mg} / \mathrm{kg}$ per d) showed lower (approximately $15 \mathrm{mmHg}$ ) systolic blood pressure than animals fed a control diet. The ACE activities in the aorta, left ventricle, and kidney were significantly decreased in the GP-hyd group compared with those of the control group and were similar to those found in SHR fed captopril (130 mg/kg per d). Impaired endothelium-dependent relaxation to acetylcholine by aortic rings from SHR was improved in those fed the GP-hyd diet. The left ventricle weight and kidney weight index were significantly reduced in the GP-hyd group and captopril groups. Moreover, long-term treatment of SHR with a diet enriched in goat milk hydrolysate, or captopril, attenuated the development of hypertension, cardiac and renal hypertrophy, and endothelial dysfunction. These effects might be related to the in vivo inhibitory effects of the hydrolysate on tissue ACE activity.
\end{abstract}

Key words: bioactive peptide, angiotensin-converting enzyme inhibitor, goat milk, spontaneously hypertensive rat

Received December 5, 2005.

Accepted April 11, 2006.

${ }^{1}$ Corresponding author: ageerlings@pulevabiotech.es

${ }^{2} \mathrm{~A}$. Geerlings and I. C. Villar contributed equally to this work.

\section{INTRODUCTION}

Peptides derived from proteins in foods have been shown to regulate physical functions in the alimentary, neuronal, and circulatory systems. Among many functional peptides, those possessing hypotensive activity are thought to be useful as functional food materials for high blood pressure patients (Meisel, 2005). This activity is mainly due to the inhibition of the angiotensin I-converting enzyme (ACE; EC 3.4.15.1), which plays 2 important roles in the regulation of blood pressure. One is the conversion of the inactive decapeptide angiotensin I to the strong vasoconstrictor and saltretaining octapeptide, angiotensin II. The other is the inactivation of the vasodilator and natriuretic nonapeptide, bradykinin.

The ACE inhibitors are well established in the therapy of hypertension and heart failure and have been shown to exert organ protective effects (Parmley, 1998). Currently, more than $10 \mathrm{ACE}$ inhibitors are available in various countries as monotherapeutic agents (Brown and Vaughan, 1998). These drugs may cause several side effects, like hypotension, reduced renal function, cough, and fetal abnormalities. This has stimulated the search for natural ACE inhibitors, and consequently several peptides have been identified in a range of food proteins (Ariyoshi, 1993).

Milk proteins are a good source of bioactive peptides, and ACE inhibitory peptides have been produced by the enzymatic hydrolysis of milk proteins and by fermentation with lactic acid bacteria (for a review see FitzGerald et al., 2004). Several milk peptides inhibit ACE in vitro (Nakamura et al., 1995a; Maeno et al., 1996; Abubakar et al., 1998; Pihlanto-Leppala et al., 2000). Some of these peptides have also been found to have antihypertensive properties in animals and human subjects. In this context, the antihypertensive activity in spontaneously hypertensive rats (SHR) of both a fermented milk prepared from skimmed milk with a starter culture containing Lactobacillus helveticus and Saccharomyces cerevisiae, and 2 biologically active peptides isolated from it, Val-Pro-Pro (VPP) and Ile-ProPro (IPP), have been reported (Nakamura et al., 1995b). 
This sour milk also reduced blood pressure in hypertensive patients (Hata et al., 1996). More recently, longterm oral intake of IPP and VPP, or a sour milk product fermented by L. helveticus LBK-16H containing these tripeptides (Sipola et al., 2001, 2002) and milk fermented by Enterococcus faecalis CECT 5728 (Miguel et al., 2005), attenuated the development of hypertension in young prehypertensive SHR. Moreover, L. helveticus LBK-16H-fermented milk containing bioactive tripeptides IPP and VPP in normal daily use had a bloodpressure-lowering effect in hypertensive patients (Seppo et al., 2003). In addition, recent in vivo studies with SHR and hypertensive human volunteers report significant blood pressure reducing effects of consuming specific milk hydrolysates and fermented dairy products (Tuomilehto et al., 2004; Aihara et al., 2005; Mizuno et al., 2005).

In this study we aimed to identify novel peptidic ACE inhibitors from a goat milk hydrolysate. Goat milk is mainly used for the preparation of cheese and has been less studied than bovine milk as a source of bioactive peptides. Three novel peptidic ACE inhibitors are reported of which at least one is able to pass a Caco-2 cell monolayer. The effect of long-term oral administration of a hydrolysate rich in these peptides was studied in SHR, focusing on blood pressure, organ damage, endothelial function, and tissue ACE activity.

\section{MATERIALS AND METHODS}

\section{Materials}

Subtilisin alcalase was a kind gift from Novozymes (Bagsværd, Denmark). Fat-free goat milk was purchased from a local supplier (Lacteas Cobreros, Zamora, Spain). Synthetic peptides ( $\beta$-CN f78-83, $\beta$-CN f84-87, and $\beta$-CN f181-184) with a purity of at least $95 \%$ were prepared by Eurosequence (Groningen, the Netherlands). The ACE enzyme (from rabbit lung), acetylcholine chloride, cellulose, N-Hippuryl-His-Leu tetrahydrate (HHL), hippuric acid, methionine, $( \pm)$-noradrenaline bitartrate, and sodium nitroprusside were from Sigma (Madrid, Spain). The Caco-2 monolayers (Cacoready) were obtained from Advancell (Barcelona, Spain). Captopril was from Bristol-Myers Squibb (New York, NY). Starch was purchased from Roquette Laisa (Valencia, Spain) and vitamin mix from Nutri Espadaler (Barcelona, Spain).

\section{Preparation of Protein Hydrolysates}

For the identification and purification of ACE-inhibitory peptides, the following hydrolysis was performed. First, the $\mathrm{pH}$ of fat-free goat milk was adjusted to 3.5 using $\mathrm{HCl}$. After coagulation, the casein fraction was separated from the whey protein by centrifugation $(5,000 \times g, 10 \mathrm{~min})$. Casein protein was then dissolved in water until a $10 \%$ protein concentrate was obtained (protein concentration in casein fraction was determined as described by Lynch et al., 1998). Alcalase enzyme was added (1\% in volume, final concentration 24 Anson units/L), and the hydrolysis was performed at $50^{\circ} \mathrm{C}$ for $2 \mathrm{~h}$. The $\mathrm{pH}$ of the suspension was maintained at 8.5 during the hydrolysis process using $\mathrm{NaOH}$ $(2 N)$. Finally, the proteinase was inactivated by heat $\left(10 \mathrm{~min}\right.$ at $\left.100^{\circ} \mathrm{C}\right)$ and the hydrolysate lyophilized in a vacuum chamber.

For the preparation of goat milk hydrolysate for in vivo studies, a similar process was performed with some small differences. First, 1,000 L of fat-free goat milk was heat treated $\left(145^{\circ} \mathrm{C}\right.$ for $\left.4 \mathrm{~s}\right)$, and protein concentrate was obtained by microfiltration using a $10-\mathrm{kDa}$ membrane (ABCOR 6338-HFK-131, Koch Membrane Systems, Wilmington, MA) in a pilot-plant installation (Invensys APV, London, UK). The reason for using microfiltration was to remove lactose from the protein. The hydrolysis was performed in the same conditions as described above in 40-L bioreactors. However, for the maintenance of the $\mathrm{pH}$ the following buffer was used: $1 \mathrm{~N} \mathrm{NaOH}, 1 \mathrm{~N} \mathrm{KOH}$, and $3 \mathrm{~N} \mathrm{Ca}(\mathrm{OH})_{2}$. Approximately $1.5 \mathrm{~L}$ of this buffer was used for the preparation of $40 \mathrm{~L}$ of hydrolysate, leading to a theoretical rate of hydrolysis of $23.8 \%$. After a heat treatment (10 min at $90^{\circ} \mathrm{C}$ ) the hydrolysate was mixed with starch (see preparation of diets) and dried in a small drying tower at $180^{\circ} \mathrm{C}$. For the preparation of goat protein, the same process was followed omitting the hydrolysis step.

\section{Purification and Identification of ACE Inhibitory Peptides}

Forty microliters of goat milk hydrolysate (100 g/L) was fractionated on a liquid chromatography system (ÄKTA explorer, GE Healthcare, Uppsala, Sweden) using a reverse-phase column (Resource RP, Amersham) and a linear gradient of $\mathrm{H}_{2} \mathrm{O} / 0.05 \%$ trifluoracetic acid and $84 \%$ acetonitrile/ $0.05 \%$ trifluoracetic acid (40 min, $1 \mathrm{~mL} / \mathrm{min})$. Forty fractions of $1 \mathrm{~mL}$ were collected and dried under vacuum, resuspended in $10 \mu \mathrm{L}$ of $\mathrm{H}_{2} \mathrm{O}$, and added to the apical site of Caco-2 monolayers. Caco2 assays were performed using 24-well plates containing Caco-2 cell monolayers according to the manufacturer's instructions. After $90 \mathrm{~min}$ of incubation at $37^{\circ} \mathrm{C}$ in a humidified cell incubator, basolateral samples were collected, dried under vacuum, resuspended in 10 $\mu \mathrm{L}$ of borate buffer, and assayed for ACE inhibitory activity. In this manner, fraction 19 (retention time = 19 min) was found to contain ACE inhibitory peptides able to pass a Caco-2 monolayer, and was used in a 
subsequent purification step. On an HPLC equipment, fraction 19 was further fractionated using a Zorbax $5 \mathrm{C} 18$ column $(2.1 \times 250 \mathrm{~mm}$, Waters, Milford, MA $)$ and the following gradient was applied; 0 to $30 \%$ in $60 \mathrm{~min}$, 30 to $80 \%$ in 10 min of $0.05 \%$ trifluoracetic acid in $\mathrm{H}_{2} \mathrm{O}$, and $0.04 \%$ trifluoracetic acid in acetonitrile (flow rate of $350 \mu \mathrm{L} / \mathrm{min}$ ). Thirty fractions were collected and assayed for ACE inhibitory activity as described above. Three fractions contained inhibitory activity and were used for peptide sequencing using Edman degradation (performed by Eurosequence).

\section{ACE Assay}

The ACE enzyme inhibition was assayed by HPLC as described (Wu et al., 2002) using HHL as substrate and pure ACE from rabbit lung. The ACE activity in the left ventricle, aorta, and kidney of SHR rats was determined by extracting $12 \mathrm{mg}$ of tissue using borate buffer (100 mmol/L, $\mathrm{pH} 8.3$ ) and a polytron homogenizer. After brief centrifugation $(1,000 \times g, 1 \mathrm{~min})$, the protein content in the supernatant was determined by the Bradford method (Bradford, 1976). Ten micrograms of protein was used in the ACE assay instead of pure ACE from rabbit lung. One unit of ACE activity is defined as 1 mole of hippuric acid formed per minute at $37^{\circ} \mathrm{C}$.

\section{HPLC Method for Quantification of Peptides}

An HPLC assay was developed for the quantification of goat $\beta$-CN f78-83, $\beta$-CN f84-87, and $\beta$-CN f181184 peptides in hydrolysates and in Caco-2 basolateral samples. This method was set up using an HPLC (Waters Alliance 2695) equipped with a diode-array detector (Waters 996 PDA), a mass spectrometer (Waters $\mathrm{MS})$, an Atlantis $\mathrm{dC} 18$ column $\left(35^{\circ} \mathrm{C}, 5 \mu \mathrm{m}, 3 \times 150\right.$ $\mathrm{mm}$, Waters), and 2 eluents (A: $0.1 \%$ formic acid; B: $100 \%$ acetonitrile). The following gradient was used: $\mathrm{t}=0 \mathrm{~min}: 90 \% \mathrm{~A}$ to $10 \% \mathrm{~B} ; \mathrm{t}=17.50 \mathrm{~min}: 80 \% \mathrm{~A}$ to $20 \% \mathrm{~B}$; $\mathrm{t}=20.00 \mathrm{~min}: 60 \% \mathrm{~A}$ to $40 \% \mathrm{~B} ; \mathrm{t}=32.00 \mathrm{~min}: 60 \% \mathrm{~A}$ to $40 \% \mathrm{~B} ; \mathrm{t}=33.00 \mathrm{~min}: 90 \% \mathrm{~A}$ to $10 \% \mathrm{~B} ; \mathrm{t}=40.00 \mathrm{~min}$ : $90 \% \mathrm{~A}$ to $10 \% \mathrm{~B}$ (flow rate: $0.25 \mathrm{~mL} / \mathrm{min}$ ). Four micrograms of hydrolysate was injected in this system and the peptides $\beta$-CN f78-83 (mass 598.80, retention time $9.97 \mathrm{~min}$ ), $\beta$-CN f84-87 (mass 444.25 , retention time $5.87 \mathrm{~min}$ ), and $\beta$-CN f181-184 (mass 458.10 , retention time $3.51 \mathrm{~min}$ ) detected by mass spectrometry (MS scan, ion mode ES+, cone voltage: $30.0 \mathrm{~V}$, scan time: 0.5 $\mathrm{s}$, data format: continuum). Previously, samples were filtered through a 10-kDa filter (Amicon, Millipore, Bilerica, MA). Basolateral samples from Caco-2 monolayers were directly injected $(10 \mu \mathrm{L})$ into this HPLC system. Peptides in these samples were quantified by
Table 1. Composition of the 3 diets fed to spontaneously hypertensive rats (amounts are per kilogram of diet, 3,970 kcal/kg of diet) ${ }^{1}$

\begin{tabular}{llll}
\hline Component, g & $\begin{array}{l}\text { GP-control } \\
\text { diet }\end{array}$ & $\begin{array}{l}\text { GP-hyd } \\
\text { diet }\end{array}$ & $\begin{array}{l}\text { Captopril } \\
\text { diet }\end{array}$ \\
\hline Goat protein hydrolysate & - & 200 & - \\
Goat protein & 200 & - & 200 \\
Captopril & - & - & 1.3 \\
Starch & 590 & 590 & 588 \\
Sugar & 100 & 100 & 100 \\
Sunflower oil & 50 & 50 & 50 \\
Vitamin mix & 10 & 10 & 10 \\
Cellulose & 50 & 50 & 50 \\
Methionine & 0.3 & 0.3 & 0.3 \\
\hline
\end{tabular}

${ }^{1} \mathrm{GP}$-control = a diet containing goat protein $;$ GP-hyd = an ad libitum diet containing goat protein hydrolysate; captopril = a diet containing goat protein and captopril.

${ }^{2}$ Vitamin mix contained vitamins $\mathrm{B}_{3}, \mathrm{~B}_{5}, \mathrm{~B}_{1}, \mathrm{~B}_{2}, \mathrm{~B}_{9}, \mathrm{~B}_{8}, \mathrm{~B}_{12}, \mathrm{~A}, \mathrm{E}$, $\mathrm{D}_{3}$, and $\mathrm{K}$ in amounts according to NRC (1995).

mass spectrometry using calibration curves prepared in the same system with synthetic peptides of at least 95\% purity.

\section{Diets}

The compositions of the 3 diets used are presented in Table 1. All diets were prepared in the pilot plant installations of Puleva Biotech. Protein hydrolysate or goat protein solutions were mixed with starch (see preparation of hydrolysates) and dried in a drying tower. Then, the remaining components of the diets were admixed and the amount of $\mathrm{Na}, \mathrm{K}$, and $\mathrm{Ca}$ determined in each diet. Diets were then equalized in $\mathrm{Na}, \mathrm{K}$, and $\mathrm{Ca}$ contents (final concentrations in diets were $\mathrm{Na}, 5.6 \mathrm{~g} /$ $\mathrm{kg} ; \mathrm{K}, 3.5 \mathrm{~g} / \mathrm{kg}$; and $\mathrm{Ca}, 15.3 \mathrm{~g} / \mathrm{kg}$ ), and finally pellets were prepared. All 3 diets were analyzed for content in peptide $\beta$-CN f78-83. Only diet supplemented with protein hydrolysate contained this peptide in an amount of approximately $2.3 \mathrm{~g} / \mathrm{kg}$ of diet.

\section{Animals and Experimental Protocol}

The antihypertensive activity of a hydrolysate rich in $\beta$-CN f78-83, $\beta$-CN f84-87, and $\beta$-CN f181-184 was studied in SHR. This study was carried out in accordance with European Union guidelines for animal care and protection. Six-week-old male SHR were obtained from Harlan Laboratories (Barcelona, Spain). All rats (5 per cage) were maintained at a constant temperature $\left(24 \pm 1^{\circ} \mathrm{C}\right)$, with a 12 -h dark/light cycle. Thirty SHR were divided into 3 groups, and during 12 wk consumed an ad libitum diet containing goat protein hydrolysate (GP-hyd group), a diet containing goat protein (GPcontrol group), or a diet containing goat protein and captopril (captopril group). During the experimental periods rats had free access to tap water, and food in- 
take was measured daily. Body weight was measured every week.

\section{Blood Pressure Measurements}

Systolic blood pressure (SBP) was measured once a week, in the morning, in nonanesthetized, restrained rats (prewarmed for 10 to $15 \mathrm{~min}$ at $35^{\circ} \mathrm{C}$ ) by tail-cuff plethysmography (digital pressure meter, LE 5000, Letica SA, Barcelona, Spain). Briefly, animals were held in a plastic tube, and their tail was put through a rubber cuff, and the cuff was inflated with air. The pressure level at which the first pulse appeared, after blood flow had been interrupted with the inflated cuff, was designated SBP. At least 7 determinations were made in every session, and the mean of the lowest 3 values within $5 \mathrm{mmHg}$ was taken as the SBP level (Duarte et al., 2001).

\section{Weight Index Calculations}

At the end of the experimental period, animals were killed and heart and kidneys were excised, cleaned, and weighed. The atria and the right ventricle were then removed and the remaining tissue (left ventricle plus septum) weighed. The heart weight index, left ventricular weight index, and kidney weight index were calculated by dividing the heart weight, left ventricular weight, and kidney weight by the body weight.

\section{Vascular Reactivity Studies}

Descending thoracic aortic rings $(3 \mathrm{~mm})$ were dissected and mounted in organ chambers filled with Krebs solution (composition in mmol/L: $\mathrm{NaCl} 118, \mathrm{KCl}$ 4.75, $\mathrm{NaHCO}_{3} 25, \mathrm{MgSO}_{4} 1.2, \mathrm{CaCl}_{2} 2, \mathrm{KH}_{2} \mathrm{PO}_{4} 1.2$, and glucose 11 ) at $37^{\circ} \mathrm{C}$ and gassed with $95 \% \mathrm{O}_{2}$ and $5 \% \mathrm{CO}_{2}$. Rings were stretched to $2 \mathrm{~g}$ of resting tension by means of $2 \mathrm{~L}$-shaped stainless-steel wires inserted into the lumen and attached to the chamber and to an isometric force-displacement transducer (Letigraph 2000 , Letica SA), respectively, as previously described (Duarte et al., 2001). The concentration-relaxation response curves to acetylcholine $\left(10^{-9}\right.$ to $\left.10^{-5} \mathrm{~mol} / \mathrm{L}\right)$ were performed in rings precontracted by $10^{-7} \mathrm{~mol} / \mathrm{L}$ of noradrenaline. The concentration-relaxation response curves to nitroprusside $\left(10^{-10}\right.$ to $\left.10^{-6} \mathrm{~mol} / \mathrm{L}\right)$ were performed in the dark in rings precontracted by $10^{-6} \mathrm{~mol} /$ $\mathrm{L}$ of noradrenaline. Relaxant responses to acetylcholine and nitroprusside were expressed as a percentage of the precontraction value.

\section{Statistic Analyses}

Results are expressed as means \pm SE means of measurements. The SBP was analyzed by 2 -way ANOVA
(ANOVA, time $\times$ treatment), and by Bonferroni's posthoc test. The rest of variables were analyzed by 1-way ANOVA with Bonferroni's posttest using GraphPad Prism version 4.00 for Windows (GraphPad Software, San Diego, CA); $P<0.05$ was considered statistically significant. Concentration-response curves (relaxation of aortic rings to acetylcholine and sodium nitroprusside) were fitted to the logistic equation: $\mathrm{E}=\mathrm{E}_{\max } /(1+$ $10^{-\mathrm{k} \times([\mathrm{drug}]-\mathrm{pD} 2)}$ ), where $\mathrm{E}_{\max }$ is the maximal effect, $\mathrm{k}$ is a factor which represents the slope of the curve, and $\mathrm{pD}_{2}$ is the drug concentration exhibiting $50 \%$ of the $\mathrm{E}_{\max }$ expressed as negative log molar.

\section{RESULTS}

\section{Identification of ACE Inhibitors}

An alignment of the amino acid sequences of the 4 main proteins found in bovine and goat milk identified differences between these 2 species $\left(\alpha_{\mathrm{S} 2}-\mathrm{CN}: 11.7 \%\right.$ difference; $\beta$-CN: $9.4 \%$ difference; $\kappa$-CN: $16.3 \%$ difference; and $\beta$-LG: $8.3 \%$ difference). Therefore, we used this lessexplored source of protein for the identification of novel ACE inhibitors. First, casein protein was separated from whey protein by acidification and centrifugation and hydrolyzed using a commercial proteinase. We used a subtilisin in this study because this proteinase had not been used before for the preparation of ACE inhibitors, thereby increasing the possibilities of finding novel ACE inhibitors. After hydrolysis the hydrolysate was fractionated by reverse-phase liquid chromatography (Figure 1A), and a total of 40 fractions were obtained and applied on the apical site of Caco-2 monolayers. After $90 \mathrm{~min}$ of incubation, basolateral samples were collected and assayed for ACE inhibitory activity (Figure 1B). One fraction (number 19) did contain ACE inhibitory peptides that were capable of passing a Caco2 monolayer and was used in a subsequent purification step using HPLC (Figure 1C). Again, several fractions were obtained and assayed for ACE inhibitory activity (data not shown). Three fractions were found to have capacity to inhibit ACE and were used for peptide sequencing. In this way, 3 peptides were identified with the following AA sequences: TGPIPN, SLPQ, and SQPK, corresponding to goat $\beta$-CN fragments f78-83, f84-87, and f181-184, respectively (Table 2).

To confirm that these peptides found were really ACE inhibitors, synthetic peptides containing identical AA sequences were prepared and assayed for ACE inhibitory activities. All 3 peptides had comparable inhibitory concentration $50 \%\left(\mathbf{I C}_{50}\right)$ values using HHL as substrate in the ACE assay (Table 2). Also, the amounts of $\beta$-CN f78-83, $\beta$-CN f84-87, and $\beta$-CN f181-184 were determined in the original hydrolysate used for purification and identification of these peptides (Table 2). 


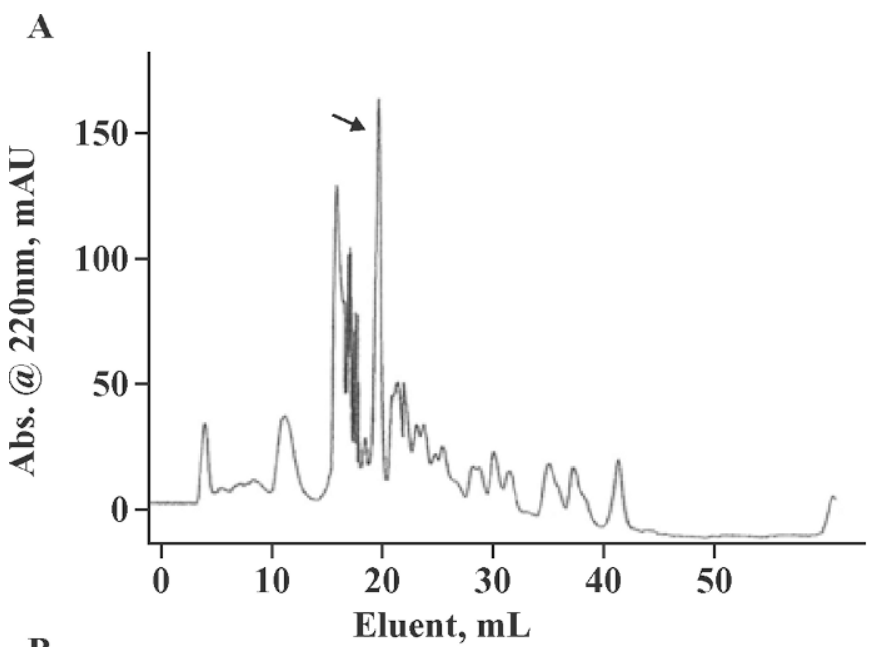

B

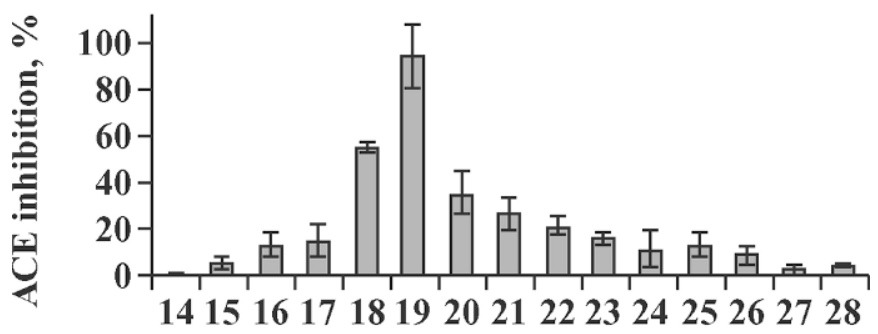

Fraction

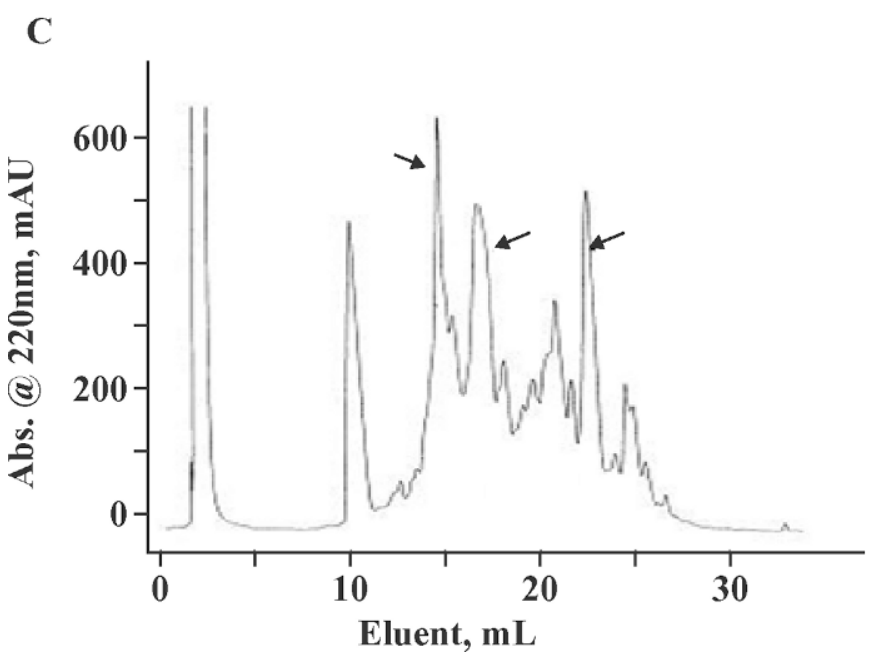

Figure 1. Chromatographic separations of goat protein hydrolysate leading to the purification of $\beta$-CN f78-83, $\beta$-CN f84-87, and $\beta$ CN f181-184. A) Chromatogram of first purification step of goat milk protein hydrolysate using reverse-phase column chromatography. The arrow indicates the fraction (fraction 19) that showed the highest angiotensin I-converting enzyme (ACE) inhibitory activity after application of the fractions to a Caco-2 monolayer and assaying basolateral samples for that activity. B) The ACE inhibitory activities after application of the fractions to a Caco-2 monolayer. C) The HPLC chromatogram of second purification step of fraction 19. Arrows indicate the fractions that showed ACE inhibitory activity and that were used for peptide sequencing (left arrow: $\beta$-CN f78-83; middle arrow: $\beta$-CN f84-87; and right arrow: $\beta$-CN f181-184).

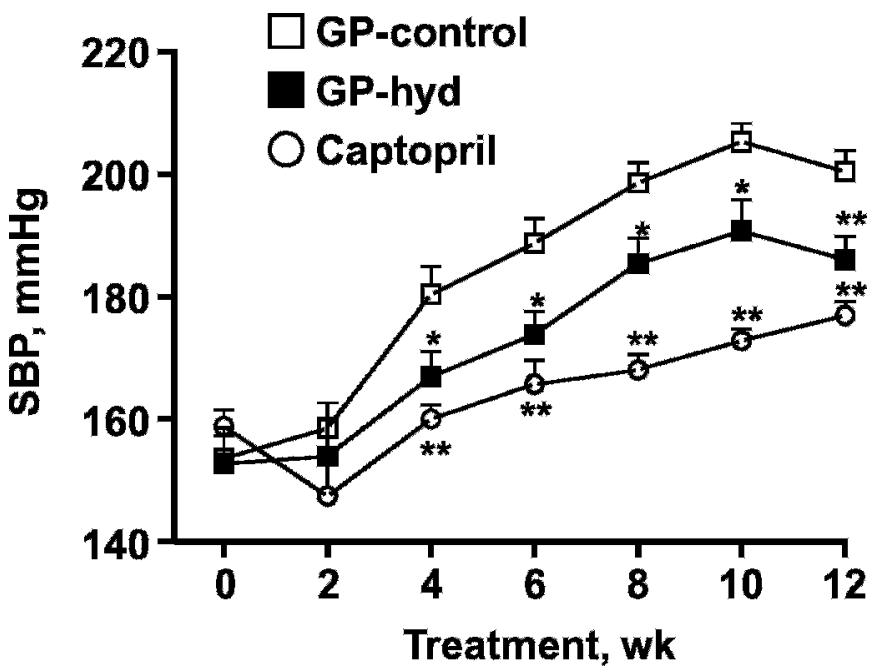

Figure 2. Systolic blood pressure (SBP) measured by tail-cuff plethysmography, in spontaneously hypertensive rats (SHR) fed a diet containing goat protein (GP-control), an ad libitum diet containing goat protein hydrolysate (GP-hyd) diet, and a diet containing goat protein and captopril (captopril) for $12 \mathrm{wk}$. Values are means \pm SEM; $\mathrm{n}=10$. Two-way ANOVA revealed a statistical significance in time and between treatments $(P<0.0005)$. ${ }^{*} P<0.05$ and $* * P<0.01$ vs. GP-control group, detected by posthoc analysis.

During the purification of the ACE inhibitory peptides, a Caco-2 monolayer was used to select for those peptides able to pass the intestinal barrier. To confirm if $\beta$-CN f78-83, $\beta$-CN f84-87, and $\beta$-CN f181-184 were able to cross this barrier, these 3 synthetic peptides were applied on the apical site of Caco-2 monolayers at a concentration of $50 \mu \mathrm{g} / \mathrm{mL}$. After $90 \mathrm{~min}$ of incubation, basolateral samples were collected and analyzed for the presence of these peptides. Only $\beta$-CN f78-83 was found to pass intact the Caco- 2 cells in small amounts (approximately $1 \%$ of the applied peptide passed to the basolateral site). The $\beta$-CN f84-87 and $\beta$-CN f181-184 were not detected at the basolateral site.

\section{Effects of Protein Hydrolysate in Spontaneously Hypertensive Rats}

Weights of the SHR fed the GP-hyd diet were significantly lower than that of rats in the GP-control and captopril groups (Table 3 ). Daily food intake throughout the study was greater in the captopril group than in the other 2 groups (Table 3). Feeding efficiencies of the GP-hyd and captopril rats were significantly lower than those in the GP-control group (Table 3). From these daily feed consumption data, the intakes of $\beta$-CN f7883 and captopril in the GP-hyd and captopril groups were calculated. Because food intake and BW changed slightly throughout the experiment, we calculated the mean intakes of $\beta$-CN f78-83 and captopril, which were 
Table 2. Angiotensin I-converting enzyme inhibitory peptides isolated from a goat milk hydrolysate with their corresponding inhibitory concentration $50 \%\left(\mathrm{IC}_{50}\right)$ values ${ }^{1}$

\begin{tabular}{lllll}
\hline Peptide & Protein & Fragment & $\mathrm{IC}_{50} \mu M$ & $\begin{array}{l}\text { Amount in } \\
\text { hydrolysate, } \\
\% \text { (by weight) }\end{array}$ \\
\hline TGPIPN & Goat $\beta$-CN & $\beta$-CN f78-83 & $316 \pm 25$ & 1.17 \\
SLPQ & Goat $\beta$-CN & $\beta$-CN f84-87 & $330 \pm 7$ & 1.09 \\
SQPK & Goat $\beta$-CN & $\beta$-CN f181-184 & $354 \pm 27$ & 0.02 \\
\hline
\end{tabular}

${ }^{1}$ Values are means $\pm \operatorname{SEM}(\mathrm{n}=3)$. The $\mathrm{IC}_{50}$ values were determined using synthetic peptides with a purity of at least $95 \%$. Using HPLC-MS and calibration curves of synthetic peptides, the amounts of these peptides were determined in the initial hydrolysate.

on average $230 \mathrm{mg} / \mathrm{kg}$ per $\mathrm{d}$ and $130 \mathrm{mg} / \mathrm{kg}$ per $\mathrm{d}$, respectively.

The SBP of the GP-control group showed a gradual increase from weaning that reached maximal values at 14 wk of life (Figure 2). Long-term goat protein hydrolysate (GP-hyd diet) feeding partly prevented the increase in SBP in SHR, and this effect reached statistical significance after wk 4 of treatment. Particularly, 2-way ANOVA revealed a statistical significance in SBP in time and treatment but failed in the interaction between time and treatment (time; $F=30.61, \mathrm{df}=5, P<$ 0.0001 , treatment; $F=29.57$, df $=1, P<0.0001$, and time vs. treatment; $F=0.49$, $\mathrm{df}=5, P=0.7851$ ). At the end of 12 wk of treatment, the GP-hyd group showed a reduction of about $15 \mathrm{mmHg}$ in SBP compared with rats in the GP-control group, whereas long-term captopril treatment also reduced significantly SBP by about $25 \mathrm{mmHg}$. Regarding captopril, 2-way ANOVA revealed a statistical significance in SBP in time, treatment, and their interaction (time; $F=29.3$, df $=5, P<0.0001$, treatment; $F=129.10, \mathrm{df}=1, P<0.0001$, and time vs. treatment; $F=2.37$, df $=5, P=0.0445$ ).

The left ventricular weight index was significantly reduced in the GP-hyd and captopril groups compared with the GP-control group. The kidney weight index was also reduced by GP-hyd and captopril treatments
(Figure 3). Captopril reduced the cardiac hypertrophy more than GP-hyd. However, the GP-hyd diet prevented the development of renal hypertrophy to a greater extent than the captopril diet.

Aortic rings from rats fed the GP-control diet showed a reduced endothelium-dependent vasodilator response to acetylcholine in arteries stimulated by noradrenaline $\left(\mathrm{E}_{\max }, 41.9 \pm 3.8 \%\right.$; Figure $\left.4 \mathrm{~A}\right)$. Aortic rings obtained from rats of the GP-hyd and captopril groups showed a significant increase in vasodilatation induced by acetylcholine compared with the GP-control group ( $\mathrm{E}_{\max }$, $54.5 \pm 4.1 \%$ and $87.5 \pm 5.3 \%$, respectively, $P<0.05$; Figure 4A). The endothelium-independent vasodilator responses to the NO donor nitroprusside, in vessels precontracted with noradrenaline, were slightly increased only by captopril treatment (Figure 4B).

The ACE activities were measured in protein extracts from different tissues (Figure 5). The SHR fed the GPhyd diet or the captopril diet for $12 \mathrm{wk}$ showed significantly lower ACE activities of the heart, aorta, and kidney compared with rats fed the GP-control diet. No significant differences in tissue ACE activity were found between GP-hyd and captopril groups.

\section{DISCUSSION}

In this study, we identified 3 new ACE inhibitory peptides, $\beta$-CN f78-83 (TGPIPN), $\beta$-CN f84-87 (SLPQ),

Table 3. Changes in BW, organ weight, food intake, and feeding efficiency of rats fed different diets ${ }^{1}$

\begin{tabular}{lccc}
\hline Item & GP-control & GP-hyd & Captopril \\
\hline Initial BW, g & $142.0 \pm 4.9$ & $152.0 \pm 3.6$ & $141.9 \pm 4.9$ \\
Final BW, g & $263.0 \pm 9.7$ & $212.2 \pm 7.0^{* *}$ & $270.0 \pm 6.4$ \\
Heart weight, mg & $948 \pm 31$ & $711 \pm 33^{* * *}$ & $816 \pm 31^{* *}$ \\
Left ventricle weight, mg & $690 \pm 23$ & $512 \pm 22^{* *}$ & $572 \pm 27^{* *}$ \\
Kidney weight, mg & $924 \pm 48$ & $616 \pm 28^{* *}$ & $861 \pm 22$ \\
Weight gain, g/rat per d & $1.44 \pm 0.08$ & $0.72 \pm 0.06^{* *}$ & $1.56 \pm 0.04$ \\
Food intake, g/rat per d & $17.5 \pm 0.3$ & $18.1 \pm 0.5$ & $21.8 \pm 0.6^{* *}$ \\
Feeding efficiency, ${ }^{*} \%$ & $8.24 \pm 0.44$ & $3.97 \pm 0.31^{* *}$ & $7.17 \pm 0.17^{* *}$ \\
\hline
\end{tabular}

\footnotetext{
${ }^{1}$ Values are means $\pm \operatorname{SEM}(\mathrm{n}=10)$.

${ }^{2}$ Feeding efficiency $=($ daily weight gain/daily food intake $) \times 100$. GP-control $=$ diet containing goat protein; GP-hyd = ad libitum diet containing goat protein hydrolysate; captopril = diet containing goat protein and captopril.

$* * P<0.01$ vs. GP-control group.
} 


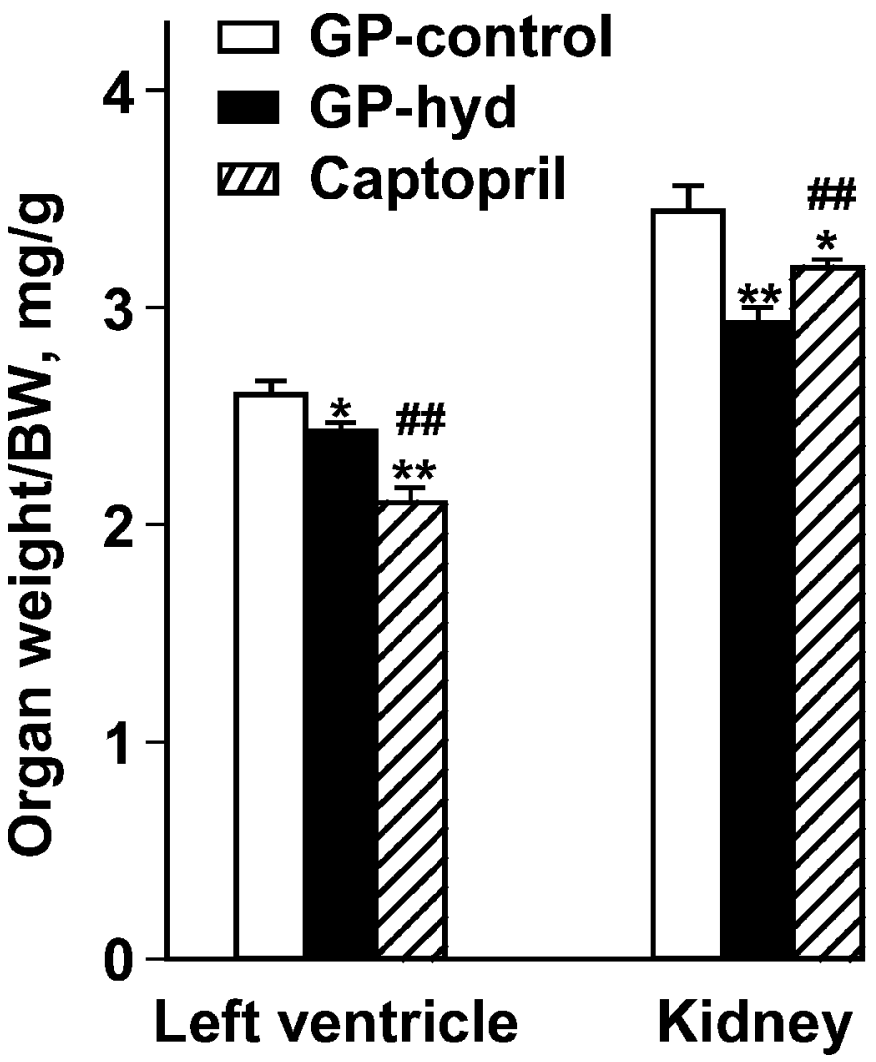

Figure 3. Effects of chronic ad libitum diet containing goat protein hydrolysate (GP-hyd) and a diet containing goat protein and captopril (captopril) on the development of left ventricular and renal hypertrophy in spontaneously hypertensive rats (SHR). Organ hypertrophy is expressed as organ weight to BW ratio. Values are means \pm SEM, $\mathrm{n}=10 . * P<0.05 ; * * P<0.01$ vs. diet containing goat protein (GPcontrol); \#\#P<0.01 vs. GP-hyd group.

and $\beta$-CN f181-184 (SQPK), from goat milk hydrolysate, of which $\beta$-CN f78-83 was capable of passing a Caco-2 monolayer. These peptides showed high $\mathrm{IC}_{50}$ values (ranging between $316-354 \mu \mathrm{mol} / \mathrm{L}$ ), as compared with captopril $(0.022 \mu \mathrm{mol} / \mathrm{L}$; Fujita and Yoshikawa, 1999), indicating weak ACE inhibitory activity in vitro. The ACE inhibitory potency of these 3 peptides are higher than that of $\beta$-lactosin B (ALPM; Murakami et al., 2004), $\beta$-LG f142-146 (ALPMH), $\beta$-LG f146-148 (HIR; Pihlanto-Leppala et al., 2000), and $\beta$-LG f146149 (HIR; Mullally et al., 1996). In contrast, lactokinin (ALPMHIR; Mullally et al., 1997) and the tripeptides VPP and IPP (Nakamura et al., 1995b) showed stronger in vitro $\mathrm{ACE}$ inhibitory activities than the peptides identified in this study. However, the $\mathrm{IC}_{50}$ values are not always a good measure of the in vivo antihypertensive activities of milk-derived peptides. For instance, Murakami et al. (2004) described a tetrapeptide (AlaLeu-Pro-Met) originating from $\beta$-LG with a high $\mathrm{IC}_{50}$ for ACE $(928 \mu M)$ but with a strong antihypertensive

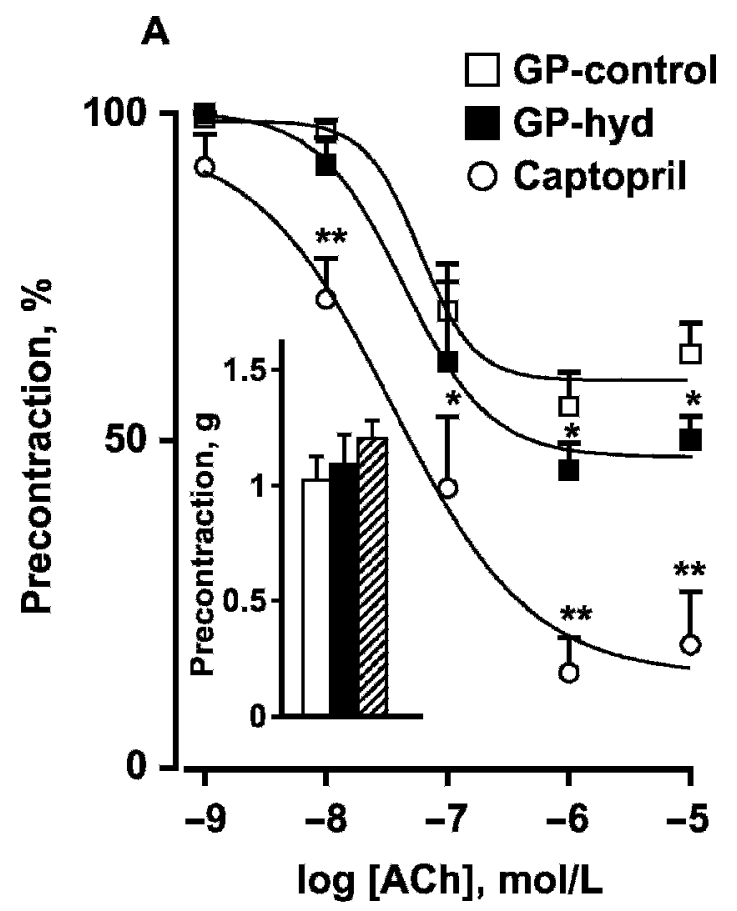

B

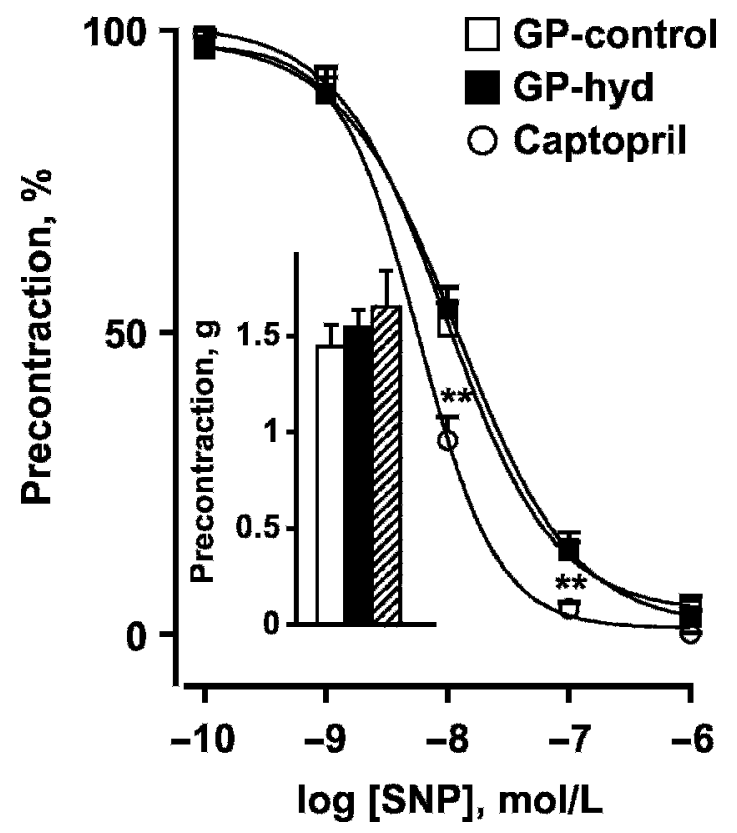

Figure 4. Relaxation of aortic rings induced by acetylcholine (Ach; A) and sodium nitroprusside (SNP; B) in spontaneously hypertensive rats (SHR) fed different diets for 12 wk. A) Endothelium-dependent relaxation in intact aortic rings. B) Endothelium-independent relaxation in denuded aortic rings. Values are means \pm SEM; $\mathrm{n}=10$ (1 aortic ring per animal, 10 animals per group). $* P<0.05$ and $* * P<$ 0.01 vs. group fed diet containing goat protein (GP-control). The insets show the contractile tension induced by noradrenaline (panel $\mathrm{A}$, $10^{-7} \mathrm{~mol} / \mathrm{L}$; panel B, $10^{-6} \mathrm{~mol} / \mathrm{L}$ ) in aortic rings from GP-control (open column), ad libitum diet containing goat protein hydrolysate (GP-hyd; solid column), or diet containing goat protein and captopril (captopril; dashed column) groups before the addition of ACh or SNP. 


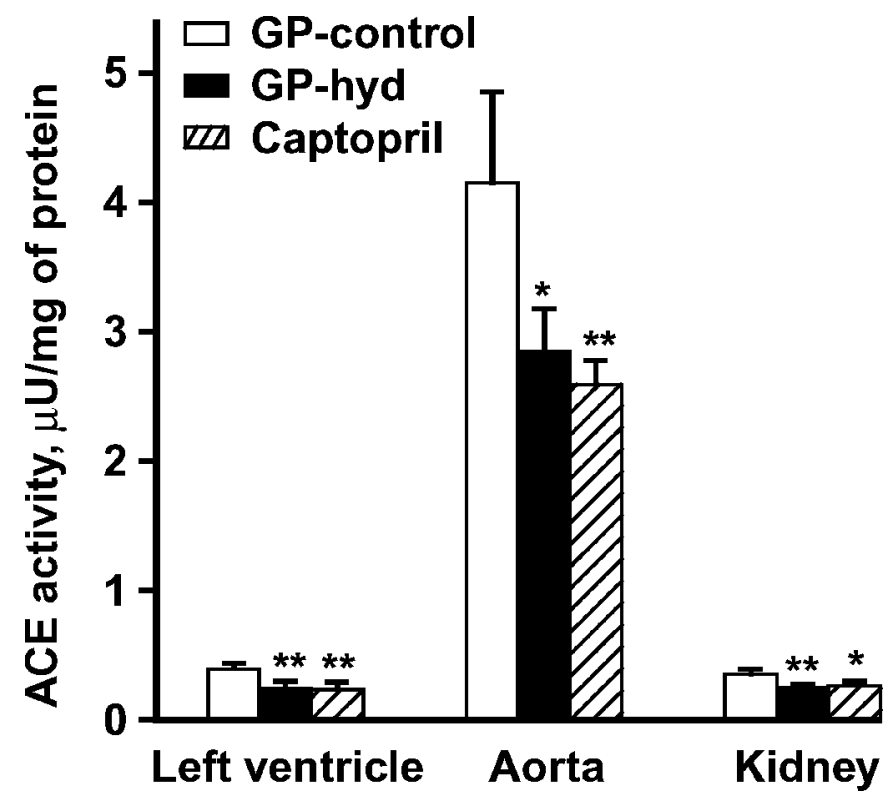

Figure 5. Angiotensin-converting enzyme (ACE) activity in different tissues from spontaneously hypertensive rats (SHR) after different treatments. Values are means \pm SEM; $n=4$. GP-control $=\mathrm{a}$ diet containing goat protein; GP-hyd = an ad libitum diet containing goat protein hydrolysate; captopril $=$ a diet containing goat protein and captopril. $* P<0.05$ and $* * P<0.01$ vs. GP-control group.

activity (-21.4 mmHg). Although in this study only the short-term effects of this peptide on hypertension were measured, it demonstrates that factors other than the $\mathrm{IC}_{50}$ value might play a role in the overall in vivo activity. One possible explanation for this is that antihypertensive peptides are further digested in the intestine, releasing smaller fragments with higher affinities for ACE. Although we have found that $\beta$-CN f78-83 is transported through Caco-2 monolayers in small amounts, we cannot rule out that this peptide is further digested before being absorbed. Further studies should clarify why some peptides with high $\mathrm{IC}_{50}$ values might have good antihypertensive activities.

We have shown that long-term intake of a diet enriched in goat protein hydrolysate containing these 3 peptides attenuated the development of hypertension, cardiac and renal hypertrophy, and endothelial dysfunction in young SHR. The SHR is considered to be a renin-independent model of hypertension in which plasma angiotensin II levels are not elevated (Campbell et al., 1995). Nevertheless, ACE inhibitors have proven to be potent and effective agents in SHR for reduction of blood pressure, and regression of several abnormalities including cardiac and renal hypertrophy and endothelial dysfunction developed in this model of genetic hypertension (Lee et al., 1991; Takai et al., 2004). This disparity can be understood if we consider that their antihypertensive effects are better related to the inhibition of tissue, rather than plasma, ACE (Takai et al., 2004). In fact, we found that chronic treatment with the GP-hyd diet or captopril reduced ACE activities significantly in target organs for hypertension, such as heart, kidney, and vascular tissues. It is interesting to note that both treatments were able to reduce ACE activity in vivo to a similar extent, despite the lower $\mathrm{IC}_{50}$ values of captopril. We might speculate that longterm consumption of milk protein hydrolysate is required for sufficient tissue concentration of the ACE inhibitors or that $\beta$-CN f78-83, the peptide that is able to cross a model of the intestinal barrier, or other peptides present in the hydrolysate, are cleaved in vivo by peptidases leading to smaller peptides with higher ACE inhibitory activities. However, further experiments are required to test if $\beta$-CN f78-83, fragments thereof, or other peptides generated by digestive enzymes are responsible for the SBP-lowering effect. In addition, our results suggest that captopril, which is more effective than the GP-hyd diet in preventing hypertension, despite inducing similar inhibitory aortic ACE activities, could present additional mechanisms involved in the control of blood pressure.

Sustained high blood pressure is one of the most powerful determinants of the development of cardiac and renal hypertrophy (Frohlich et al., 1992). In fact, SHR are characterized by increased heart and kidney relative weights compared with normotensive WKY rats (Duarte et al., 2001). Daily consumption of a GP-hyd diet or a captopril diet prevented the cardiac and renal hypertrophy found in SHR. Captopril was superior to goat milk hydrolysate in preventing cardiac hypertrophy, whereas kidney protection induced by goat milk hydrolysate was superior to that evoked by captopril. The suppression of cardiac hypertrophy induced by captopril is not completely understood. It does not appear to be related to the antihypertensive properties of this ACE inhibitor alone (Chen et al., 1998). Our data of kidney hypertrophy are in agreement with those of Dworkin et al. (1989) who found that captopril produces renal abnormalities via a mechanism not dependent on the presence of systemic hypertension.

The endothelium is crucial for the modulation of vessel tone and for the control of platelet adhesion and aggregation. Endothelial dysfunction, defined as an imbalance of endothelial-derived vasoactive factors leading to vasoconstriction and structural changes in the vessel wall, is an early event in the pathophysiology of atherosclerosis and hypertension, and it is an independent predictor of poor prognosis (Schachinger et al., 2000). The key alterations in vasoactive factors characteristic of endothelial dysfunction include diminished bioavailability of $\mathrm{NO}$ and enhanced release of reactive 
oxygen species, endothelin-1, and vasoconstrictor prostanoids (Vanhoutte, 1996; Yang et al., 2003). The ACE inhibitors tend to be more beneficial than the traditional combination therapy (hydralazine plus hydrochlorothiazide), despite a comparable blood pressure reduction, which raises the possibility that the reninangiotensin system blockade, in addition to lowering blood pressure, may be important in reversing endothelial dysfunction in hypertension (Onaka et al., 1998). In the present study, we report for the first time that the long-term treatment with a milk protein hydrolysate improved the endothelial function in isolated arteries from hypertensive animals, increasing the impaired endothelium-dependent relaxation response to acetylcholine. The endothelium-independent vasodilatation induced by the soluble guanylate cyclase activator nitroprusside was unaffected by GP-hyd diet, indicating that its improvement of endothelial dysfunction was due to changes in endothelial-derived NO availability rather than downstream effects on vascular smooth muscle. This observation parallels those made in previous studies performed in in vitro studies, in which treatment with the tetrapeptides $\alpha$-lactorphin and $\beta$-lactorphin restored endothelium-dependent responses to agonists in mesenteric arteries from adult SHR (Sipola et al., 2002).

The endothelial protective effects of the milk protein hydrolysate might be related to the reduced ACE activity found in the aorta of SHR consuming this GP-hyd diet. Several actions derived from its inhibitory ACE activity could contribute to the improved endothelial function, including inhibition of angiotensin II-mediated superoxide generation via NADPH-oxidase activation due to the reduced local concentration of angiotensin II in this tissue and increased NO production derived from enhanced bradykinin levels in the vessel wall (Rodrigo et al., 1997).

In conclusion, we have shown that peptides obtained by hydrolyzing goat milk protein (TGPIPN, SLPQ, and SQPK) inhibit ACE activity in vitro. Long-term treatment with a diet containing milk protein hydrolysate partly prevents the development of hypertension, improving target organ damage and endothelial function in SHR. These protective effects might be related to decreased ACE activity in vivo in the heart, kidney, and aorta. These results suggest that the increase in blood pressure could be partially prevented by taking these peptides derived from milk protein. Finally, we expect that such a protein hydrolysate could be used as a functional food to control blood pressure in patients with essential hypertension.

\section{ACKNOWLEDGMENTS}

The authors wish to thank Federico Lara Villoslada and Jose Miguel Carrion Dengra for their help in the preparation of the diets used in this study, and Emilia Guadix of the University of Granada for excellent advice on the preparations of protein hydrolysates.

\section{REFERENCES}

Abubakar, A., T. Saito, H. Kitazawa, Y. Kawai, and T. Itoh. 1998. Structural analysis of new antihypertensive peptides derived from cheese whey protein by proteinase K digestion. J. Dairy Sci. 81:3131-3138.

Aihara, K., O. Kajimoto, H. Hirata, R. Takahashi, and Y. Nakamura. 2005. Effect of powdered fermented milk with Lactobacillus helveticus on subjects with high-normal blood pressure or mild hypertension. J. Am. Coll. Nutr. 24:257-265.

Ariyoshi, Y. 1993. Angiotensin-converting enzyme inhibitors derived from food proteins. Trends Food Sci. Technol. 4:139-144.

Bradford, M. M. 1976. A rapid and sensitive method for the quantitation of microgram quantities of protein utilizing the principle of protein-dye binding. Anal. Biochem. 72:248-254.

Brown, N. J., and D. E. Vaughan. 1998. Angiotensin-converting enzyme inhibitors. Circulation 97:1411-1420.

Campbell, D. J., A. M. Duncan, A. Kladis, and S. B. Harrap. 1995. Angiotensin peptides in spontaneously hypertensive and normotensive Donryu rats. Hypertension 25:928-934.

Chen, S., J. Su, K. Wu, W. Hu, D. G. Gardner, and D. Chen. 1998. Early captopril treatment prevents hypertrophy-dependent gene expression in hearts of SHR. Am. J. Physiol. 274:R1511-R1517.

Duarte, J., R. Perez-Palencia, F. Vargas, M. A. Ocete, F. Perez-Vizcaino, A. Zarzuelo, and J. Tamargo. 2001. Antihypertensive effects of the flavonoid quercetin in spontaneously hypertensive rats. Br. J. Pharmacol. 133:117-124.

Dworkin, L. D., M. Grosser, H. D. Feiner, M. Ullian, and M. Parker. 1989. Renal vascular effects of antihypertensive therapy in uninephrectomized SHR. Kidney Int. 35:790-798.

FitzGerald, R. J., B. A. Murray, and D. J. Walsh. 2004. Hypotensive peptides from milk proteins. J. Nutr. 134:980S-988S.

Frohlich, E. D., C. Apstein, A. V. Chobanian, R. B. Devereux, H. P. Dustan, V. Dzau, F. Fauad-Tarazi, M. J. Horan, M. Marcus, and B. Massie. 1992. The heart in hypertension. N. Engl. J. Med. 327:998-1008.

Fujita, H., and M. Yoshikawa. 1999. LKPNM: A prodrug-type ACEinhibitory peptide derived from fish protein. Immunopharmacology 44:123-127.

Hata, Y., M. Yamamoto, M. Ohni, K. Nakajima, Y. Nakamura, and T. Takano. 1996. A placebo-controlled study of the effect of sour milk on blood pressure in hypertensive subjects. Am. J. Clin. Nutr. 64:767-771.

Lee, R. M., K. H. Berecek, J. Tsoporis, R. McKenzie, and C. R. Triggle. 1991. Prevention of hypertension and vascular changes by captopril treatment. Hypertension 17:141-150.

Lynch, J. M., D. M. Barbano, and J. R. Fleming. 1998. Indirect and direct determination of the casein content of milk by Kjeldahl nitrogen analysis: Collaborative study. J. AOAC Int. 81:763-774.

Maeno, M., N. Yamamoto, and T. Takano. 1996. Identification of an antihypertensive peptide from casein hydrolysate produced by a proteinase from Lactobacillus helveticus CP790. J. Dairy Sci. 79:1316-1321.

Meisel, H. 2005. Biochemical properties of peptides encrypted in bovine milk proteins. Curr. Med. Chem. 12:1905-1919.

Miguel, M., B. Muguerza, E. Sanchez, M. A. Delgado, I. Recio, M. Ramos, and M. A. Aleixandre. 2005. Changes in arterial blood pressure in hypertensive rats caused by long-term intake of milk fermented by Enterococcus faecalis CECT 5728. Br. J. Nutr. 94:36-43.

Mizuno, S., K. Matsuura, T. Gotou, S. Nishimura, O. Kajimoto, M. Yabune, Y. Kajimoto, and N. Yamamoto. 2005. Antihypertensive effect of casein hydrolysate in a placebo-controlled study in subjects with high-normal blood pressure and mild hypertension. Br. J. Nutr. 94:84-91.

Mullally, M. M., H. Meisel, and R. J. FitzGerald. 1996. Synthetic peptides corresponding to alpha-lactalbumin and beta-lactoglobu- 
lin sequences with angiotensin-I-converting enzyme inhibitory activity. Biol. Chem. Hoppe Seyler 377:259-260.

Mullally, M. M., H. Meisel, and R. J. FitzGerald. 1997. Identification of a novel angiotensin-I-converting enzyme inhibitory peptide corresponding to a tryptic fragment of bovine beta-lactoglobulin. FEBS Lett. 402:99-101.

Murakami, M., H. Tonouchi, R. Takahashi, H. Kitazawa, Y. Kawai, H. Negishi, and T. Saito. 2004. Structural analysis of a new antihypertensive peptide (beta-lactosin B) isolated from a commercial whey product. J. Dairy Sci. 87:1967-1974.

Nakamura, Y., N. Yamamoto, K. Sakai, A. Okubo, S. Yamazaki, and T. Takano. 1995a. Purification and characterization of angiotensin I-converting enzyme inhibitors from sour milk. J. Dairy Sci. 78:777-783.

Nakamura, Y., N. Yamamoto, K. Sakai, and T. Takano. 1995b. Antihypertensive effect of sour milk and peptides isolated from it that are inhibitors to angiotensin I-converting enzyme. J. Dairy Sci. 78:1253-1257.

National Research Council. 1995. Nutrient Requirements of Laboratory Animals. 4th rev. ed. Natl. Acad. Press, Washington, DC.

Onaka, U., K. Fujii, I. Abe, and M. Fujishima. 1998. Antihypertensive treatment improves endothelium-dependent hyperpolarization in the mesenteric artery of spontaneously hypertensive rats. Circulation 98:175-182.

Parmley, W. W. 1998. Evolution of angiotensin-converting enzyme inhibition in hypertension, heart failure, and vascular protection. Am. J. Med. 105:27S-31S.

Pihlanto-Leppala, A., P. Koskinen, K. Piilola, T. Tupasela, and H. Korhonen. 2000. Angiotensin I-converting enzyme inhibitory properties of whey protein digests: Concentration and characterization of active peptides. J. Dairy Res. 67:53-64.

Rodrigo, E., R. Maeso, R. Munoz-Garcia, J. Navarro-Cid, L. M. Ruilope, V. Cachofeiro, and V. Lahera. 1997. Endothelial dysfunction in spontaneously hypertensive rats: Consequences of chronic treatment with losartan or captopril. J. Hypertens. 15:613-618.

Schachinger, V., M. B. Britten, and A. M. Zeiher. 2000. Prognostic impact of coronary vasodilator dysfunction on adverse long-term outcome of coronary heart disease. Circulation 101:1899-1906.

Seppo, L., T. Jauhiainen, T. Poussa, and R. Korpela. 2003. A fermented milk high in bioactive peptides has a blood pressurelowering effect in hypertensive subjects. Am. J. Clin. Nutr. 77:326-330

Sipola, M., P. Finckenberg, R. Korpela, H. Vapaatalo, and M. L. Nurminen. 2002. Effect of long-term intake of milk products on blood pressure in hypertensive rats. J. Dairy Res. 69:103-111.

Sipola, M., P. Finckenberg, J. Santisteban, R. Korpela, H. Vapaatalo, and M. L. Nurminen. 2001. Long-term intake of milk peptides attenuates development of hypertension in spontaneously hypertensive rats. J. Physiol. Pharmacol. 52:745-754.

Takai, S., D. Jin, M. Sakaguchi, and M. Miyazaki. 2004. Significant target organs for hypertension and cardiac hypertrophy by angiotensin-converting enzyme inhibitors. Hypertens. Res. 27:213219

Tuomilehto, J., J. Lindstrom, J. Hyyrynen, R. Korpela, M. L. Karhunen, L. Mikkola, T. Jauhiainen, L. Seppo, and A. Nissinen. 2004. Effect of ingesting sour milk fermented using Lactobacillus helveticus bacteria producing tripeptides on blood pressure in subjects with mild hypertension. J. Hum. Hypertens. 18:795-802.

Vanhoutte, P. M. 1996. Endothelial dysfunction in hypertension. J. Hypertens. 14:S83-S93.

Wu, J., R. E. Aluko, and A. D. Muir. 2002. Improved method for direct high-performance liquid chromatography assay of angiotensinconverting enzyme-catalyzed reactions. J. Chromatogr. 950:125-130.

Yang, D., M. Feletou, N. Levens, J. N. Zhang, and P. M. Vanhoutte. 2003. A diffusible substance(s) mediates endothelium-dependent contractions in the aorta of SHR. Hypertension 41:143-148. 